\title{
THE DOWNTONIAN OR PRIDOLIAN FROM THE POINT OF VIEW OF THE BALTIC SILURIAN
}

The defining of the Silurian-Devonian boundary has caused a need for regulating the subdivision of the Upper Silurian into series. At present the distinction between the Wenlockian and Gedinnian of the two series can be taken as universally recognized, but their nomenclature and boundaries are far from being clear.

In treating the same problem, Martinsson (1969) has made two fairly reasonable suggestions: (1) to keep the type area of the Silurian System and its series in the Welsh Borderland as hitherto, and (2) to use the series names Llandoverian. Wenlockian, Ludlovian and Downtonian whenever possible... (p. 160).

Unfortunately, international practice has not followed this line. On the contrary, it has increasingly begun to make use of a mixed nomenclature - Ludlovian and Pridolian. At the same time it appears to be accepted (with varying degrees of doubt) that the Ludlovian-Downtonian boundary in Great Britain lies at the same level as the KopaninanPridolian boundary in Czechoslovakia (Berry, Boucot, 1970, 1973; ChluDač et al., 1972: Bassett, Cocks, 1974, etc.). The term Pridolian has also been preferred by the Commission on Ordovician and Silurian Systems of the Interdepartmental Stratigraphical Committee of the USSR, but it is stressed that the Pridolian and Downtonian are not full equivalents (see also Корень, Кальо, 1976).

The idea of full coincidence of these boundaries is also often used irrespective of the series nomenclature (e. g., Lawson, 1971); and only in rare cases has it been indicated that the problem of the correlation between the bases of the Downtonian and the Pridolian has remained unsettled (Jaeger, 1975; Table).

In my opinion such a situation is due to the fact that the researchers still do not see the real differences in the age of these boundaries. One of the aims of the present article is to show this difference on the basis of evidence from the Baltic area (East Baltic, Gotland and Poland).

The table gives the basic data on the correlation, and only some comments should be added. In its construction, three main groups have been used - ostracodes and conodonts for correlation with Great Britain and graptolites and conodonts for comparison with the Bohemian sections. As for the Baltic area, ostracodes are the most important (see the works mentioned in the table, Сарв, 1977, etc.), by which it is possible to correlate correctly the corresponding strata. The table has been drawn for the whole Upper Silurian, but chief attention has been paid to the boundary strata of the two series.

The scheme of East Baltic ostracode zones by L. Gailite (Гайлите, Ульст, 1974) has been somewhat changed by us in the light of the mate- 


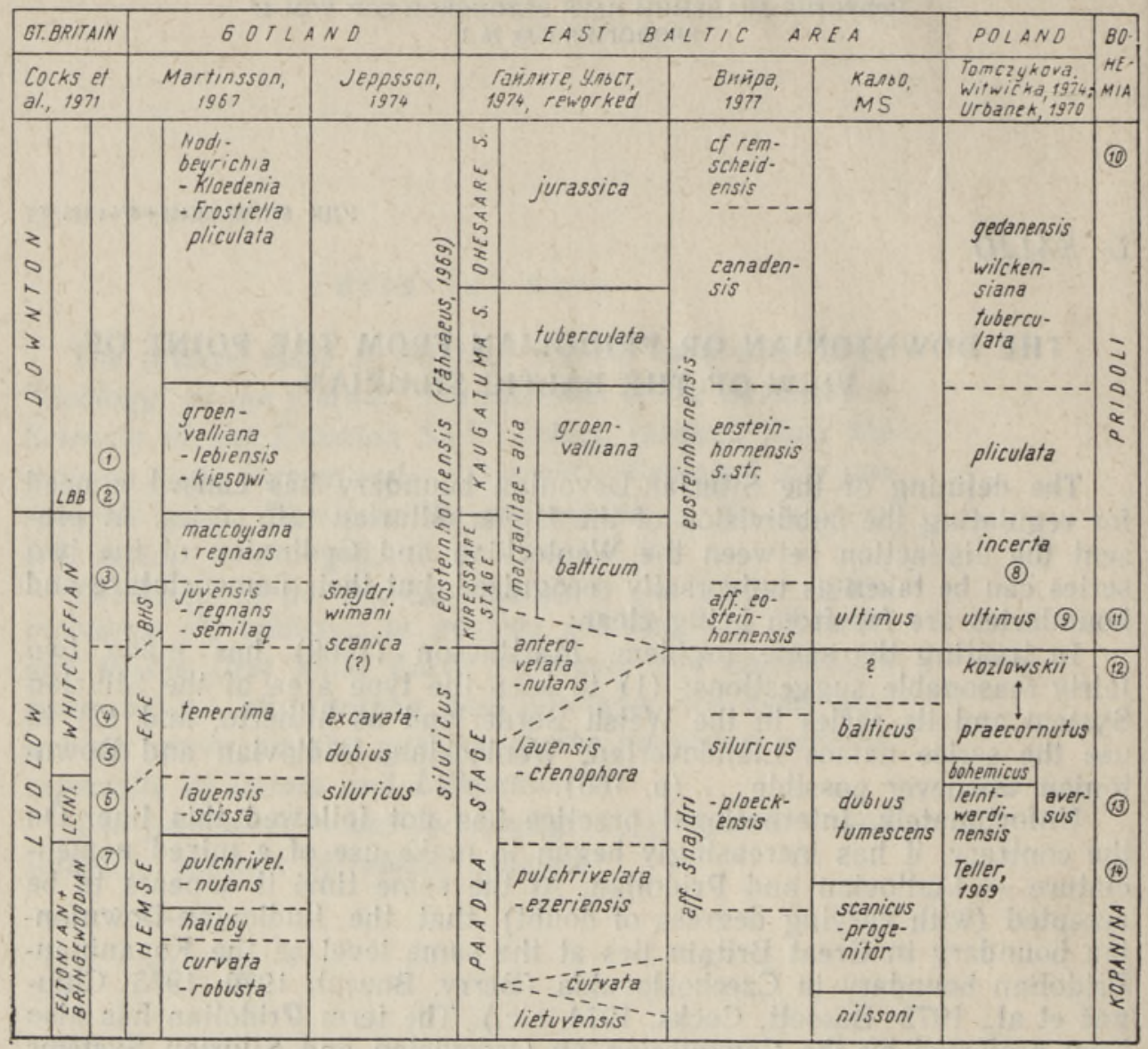

Table. Correlation of some Upper Silurian zonal schemes of the Baltic area Explanations: 1 - Frostiella groenvalliana and Londinia cf. kiesowi occur in the lowermost beds of the Downton Castle Sandstone (Martinsson, 1967: 376); 2 - in the Ludlow Bone-Bed Katoporus tricavus, Goniporus alatus, Thelodus trilobatus et al. (Turner, 1973), occurring in the Kuressaare Stage and higher (Märss, pers. comm.), are identified; 3 - conodonts of the eosteinhornensis Zone appear for the first time in the Upper Whitcliffian (Aldridge, 1975); 4 - in the Lower Whitcliffian there occurs a «faunas of Hindeodella excavata (Jeppsson, 1974); 5 - in the lowermost Whitcliffian Bohemograptus bohemicus tenuis is found, allowing us to correlate these beds with the proliferation-zone of the named species (Holland, Palmer, 1974); $6-$ Neobeyrichia lauensis occurs in the Saetograptus leintwardinensis Zone (Martinsson, 1967; Holland, Palmer, 1974); 7 - in the Brindgewoodian Kockelella variabilis occurs (Aldridge, 1975); 8 - the occurrence of Acastella prima, Acaste dayiana, A. podolica (the last two at the top of the zone and in the next one.) The first species has also been recognized in the Downtonian of the Lake district in Great Britain (Tomczykowa, Witwicka, 1974), the others are characteristic of the Skala Stage and the Köbbinghäuser Beds (Schrank, $1970) ; 9$ - in North Poland the M. ultimus Zone, overlying the $N$. kozlowskii Zone (Urbanek, 1970), like the entire Podlasian, has a fairly great thickness. Tomczyk (1964) suggested that $M$. ultimus occurs higher than $M$. formosus, but the data by Urbanek (1970) and also by Horny (1962) show a practically contemporaneous appearance of these species; $10-S$. S. remscheidensis has been identified also below of the first appearance of M. uniformis (Chlupač et al., 1972); 11 - the lower boundary of the Pridolian is marked by the first appearance of S. S. eosteinhornensis (Walmsley et al., 1974) together with $M$. ultimus and $M$. parultimus (Horny, 1962; Jaeger, 1975); 12 single specimens of $S$. s. eosteinhornensis have been found in the very topmost beds of the Kopanina in the Kosov quarry (Walliser, 1964, 1971). In the middle of the Kopanina Polygnathoides siluricus (13) and Kockelella variabilis (14) have been recognized (Walmsley et al., 1974). 
rials obtained by L. Sarv (Сарв, 1977; Кальо, Сарв, 1976). A more exact treatment of this problem is given in a forthcoming paper, and here we will restrict ourselves to the following.

The Neobeyrichia lauensis and $N$. ctenophora zone can be distinguished quite clearly in the East Baltic, but the distribution of the Hoburgiella anterovelata - Neobeyrichia nutans assemblage causes certain difficulties, as does the asynchronous appearance of the Hemsiella margaritae - Neobeyrichia alia assemblage. This is due to facies changes in the sequence. But in this case it is more important to consider the facts proving this or another variant of the correlation of sequences.

Many ostracodes of the Eke Beds, such as Hemsiella loensis (occurs also higher), $H$. anterovelata, Hoburgiella tenerrima, etc., are distributed in the upper part of the Paadla Stage (Гайлите et al., 1967; Сарв, 1968, $1971,1977)$. In the same way, a number of species characterizing the Hamra-Sundre beds occur for the first time in the lower beds of the Kuressaare Stage (Navibeyrichia balticivaga, Neobeyrichia regnans, Cryptolopholobus semilaqueatus). In the top of the stage Retisacculus semicolonatus and Juviella juvensis also occur beside them.

Considering also other relations between the ostracode faunas, I think the correlation of the Kuressaare Stage (in the new scope, see Аалоэ et al., 1976) with the Burgsvik (in part), Hamra and Sundre beds fairly certain.

The analysis of conodont distribution also leads us to such a conclusion. The beginning of the eosteinhornensis zone in the Baltic region is of particular interest. At first the base of the zone appears to coincide with the upper boundary of the Paadla Stage in the East-Baltic and with some level in the Burgsvik Beds of Gotland (see the table). But in the uppermost Eke Beds Jeppsson (1974) has described a new subspecies of Hindeodella steinhornensis scanica which up to that time had evidently been identified as Spathognathodus steinhornensis eosteinhornensis. Viira (Вийра, 1977) also recognized in the lowermost beds of the Kuressaare Stage an "untypical" S. s. eosteinhornensis and in her opinion (pers. comm.) these two forms are very close, if not identical. It is difficult to judge without taxonomic revision what stratigraphical significance they will have and what their relations are with the first $S$. s. eosteinhornensis in other regions. Still it seems possible to conclude that, in spite of the taxonomical indistinctness of the most ancient representatives, the whole the Spathognathodus steinhornensis group appears for the first time at approximately the same level in the uppermost Ludlovian or at the very beginning of the Pridolian.

Kockelella variabilis and Polygnathoides siluricus also occur in the middle of the Ludlovian of several regions of Europe (see Table, remarks $7,13,14)$. In the East Baltic they have been reported by Viira (Вийра, 1977 and pers. comm.) in the sections of the Kunkoyai and Vidukle borings. Even though many conodont zones defined by Walliser (1964, 1971) in the Upper Silurian of the Carnic Alps are not found in other areas, the mentioned species, and the forms accompanying them, still make a good basis for correlation.

Information on graptolites at this level in Baltic sections is comparatively scarce, but it still allows us to conclude that the ostracode zone of Undulirete baltica (or its analogue the zone of Neobeyrichia incerta) in general does not exceed the limits of the graptolite zone of M. ultimus. This conclusion is based on the co-occurrence of graptolites and ostracodes in the sections of the Dubovskoye boring (Кальо, Сарв, 1976, in the lowermost part of the zone M. parultimus occurs), Krynicza Morska 
(Tomczykowa, Witwicka, 1974, in the uppermost part of the zone M. ultimus has been identified).

The discovery of the graptolite Monograptus cf. boučeki in the well Leba 1 calls for special attention. There have been several interpretations of its age (mainly the Latest Kopanina, see Martinsson, 1964), in which due importance was not yet attributed to the fact that below M. cf. boučeki $M$. ex gr. formosus occurs in an interval comprising more than $200 \mathrm{~m}$ of the section. Schrank (1970) included a personal communication by Jaeger who concluded that the age of the finds is the Pridolian in age. In my opinion, this conclusion agrees best of all with other data on the Leba section. Here I would like to express a wish that graptolite specialists who have corresponding palaeontological material should make an accurate description of this important form, which probably does not occur in the Leba boring, only.

The correlation of the sections of the Baltic area is given in the table. Their correlation with the stratotype sections in the Welsh Borderland is difficult, but, as has been shown already by Martinsson (1967), it can be achieved with reasonable certainty. In our table we have mainly followed Martinsson, with some additions (see remarks $1-7$ to Table).

As for the Ludlow Bone-Bed (LBB), it is worth pointing out that there are none of the thelodonts in it which in the East Baltic are restricted to the Kuressaare Stage and the lowermost beds of the Kaugatuma Stage (e.g., Thelodus sculptilis). These data allow us to suggest that the Kuressaare Stage and its analogues (Burgsvik, Hamra and Sundre Beds) may lie below the LBB, and that they correspond to the Upper Whitcliffian within the range of $S$. s. eosteinhornensis (in its usual sense). Consequently, these stratigraphical subdivisions in the Baltic area correspond to the top of the Ludlovian Stage in its original sense (see Cocks et al., 1971).

The correlation with the Bohemian section (see Table) does not cause special difficulties, since both graptolites and conodonts provide the necessary evidence. It is useful to make only two remarks. Firstly, there is no need to overestimate the importance of the rare finds of S. s. eosteinhornensis in the uppermost beds of the Kopanina (see remark 12), at least their correlative significance, in the light of the data by Jeppsson (1974). Secondly, we should pay attention to the remark by Chlupač et al. (1972), that the boundary beds of the Kopanina and Pridoli have not been sufficiently studied, i. e., some changes are possible.

Drawing the lower boundary of the Pridolian at the base of the graptolite zone of M. ultimus and the conodont zone of S. s. eosteinhornensis, I correlate the Kuressaare Stage and Hamra-Sundre Beds with the lowermost beds of this series. We have no material at our disposal by which we could correlate the upper boundary of the Pridolian with some level in the sequence of the British Isles, and we have no data, either, to correlate the LBB with a certain horizon within the Pridolian.

And the last remark - the available data on the joint occurrences of graptolites and conodonts (Walliser, 1964, 1971; Bultynck, Pelhate, 1971; Jaeger, 1975) show that S. s. eosteinhornensis has not been found with certainty below the M. ultimus zone up to this time.

In this way, the material from the Baltic area, and also from Great Britain, (considering also the last remark above), reveals an essential difference in the position of the lower boundaries of the Downtonian and Pridolian Series. In Gotland this difference is measured by the scope of the Burgsvik (perhaps only partially), Hamra and Sundre Beds, and southwards from the island also by the ostracode zone of Hemsiella mac- 
coyiana - Neobeyrichia regnans; in the East Baltic by the Kuressaare Stage; in Poland evidently by the M. ultimus Zone.

Such a difference is too great for using the mixed British-Bohemian nomenclature for the Upper Silurian series.

The immediate consequences of this correlation would be either (1) if a mixed British-Bohemian-succession of series is applied in international usage, the classical range of the Ludlovian will have to be restricted by referring a considerable part of the Whitcliffian to the Pridolian or (2) accept the Bohemian nomenclature for the entire Upper Silurian. It seems to me that such solutions would be accepted only by a few specialists.

Evidently the only rational solution of the problem would be to agree with the suggestion made by Martinsson, cited at the beginning of this paper, i. e., to use the terms Ludlovian and Downtonian and try to find additional criteria for defining their boundaries. The approach used by Jeppsson in distinguishing Hindeodella steinhornensis scanica is a step in this direction.

The author expresses his gratitude to his colleagues V. Viira, T. Märss and L. Sarv for data used in the paper, to H. Jaeger (Berlin) for identifying $M$ parultimus in the section of the Dubovskoye boring, to A. Martinsson (Uppsala) and L. R. M. Cocks (London) for critical reading of the manuscript and for many linguistic corrections.

\section{REFERENCES}

Aldridge, R. J. 1975. The stratigraphic distribution of conodonts in the British Silurian. J. geol. Soc. London, 131, 607-618.

B a sset. M. G., C ocks, L. R. M. 1974. A review of Silurian brachiopods from Gotland. Fossils and Strata, No. 3, 56 p.

Berry, W. B. N., Boucot, A. J. (Editors). 1970. Correlation of the North American Silurian Rocks. Geol. Soc. Amer., Spec. paper, 102, 289 p.

Berry, W. B. N., B oucot, A. J. (Editors). 1973. Correlation of the African Silurian Rocks. Geol. Soc. Amer., Spec. paper, 147, 83 p.

Bultynck, P., Pelh ate, A. 1971. Découverte de la zone eosteinhornensis (Conodontes) dans le synclinorium median du Massif armorican. Mém. Bureau rech. géol. et minières, No. 73, 189-196.

Cocks, L. R. M., Holland, C. H., Rickards, R. B., Strachan, I. 1971. A correlation of Silurian rocks in the British Isles. J. geol. Soc. London, 127, $103-136$.

Chlupač, I., J a eger. H., Z Z kmundova, J. 1972. The Silurian-Devonian boundary in the Barrandian. Bull. Canad. Petrol. Geol., 20, 104-174.

Fåhraeus, L. E. 1969. Conodont zones in the Ludlovian of Gotland and a correlation with Great Britain. Sver. Geol. Undersőkn., ser. C, Nr. 639, avh. och Upps Årsbok 63, No. 2.

Holla nd, C. H., Palmer, D. C. 1974. Bohemograptus, the youngest graptoloid known from the British Silurian sequence. In: Graptolite studies in honour of O. M. B. Bulman. Spec. papers in Palaeontol., 13, 215-236.

Horny, R. 1962. Das mittelböhmische Silur. Geologie, 11, 873-916.

J a e ger, H. 1975. Die Graptolithenführung im Silur/Devon des Cellon-Profils (Karnische Alpen). Carinthia II, 111-126.

Je p p s s o n, L. 1974. Aspects of Late Silurian conodonts. Fossils and Strata, No. 6, 54 p.

$\mathrm{L}$ a w S O n, J. D. 1971. Some problems and principles in the classification of the Silurian system. In: Colloque Ordovicien-Silurien, Brest, Sept. 1971. Mém. Bureau rech. gèol. et minières, No. $73,301-308$.

Martinsson, A. 1964. Palaeocope ostracodes from the well Leba 1 in Pomerania. Geol. fören. i Stockholm förhandl., 86, 125-161.

Martinsson, A. 1967. The succession and correlation of ostracode faunas in the Silurian of Gotland. Geol. fören. i Stockholm förhandl., 89, 350-386.

Martinsson, A. 1969. The series of the redefined Silurian System. Lethaia, 2, $153-161$.

Schrank, E. 1970. Die Trilobiten des Silurs der Bohrung Leba 1 (Ostseeküste der V. R. Polen). Ber. Dtsch. Ges. geol. Wiss. Reihe A. Geol. Paläont., 15, $573-586$. 
Teller, L. 1969. The Silurian biostratigraphy of Poland based on graptolites. Acta geol. Polon., 19, 393-501.

T o m czyk, H. 1964. Stratygrafia sylura w polnocnowschodniej Polsce. Kwart. geol,, 8, 506-520.

Tomczy kowa, E., Witwicka, E. 1974. Stratigraphic correlation of Podlasian deposits on the basis of ostracodes and trilobites in the Peri-Baltic area of Poland (Upper Silurian). Biul. Inst. Geol., 276, 55-84.

Turner, S. 1973. Siluro-Devonian thelodonts from the Welsh Borderland. J. Geol. Soc. London, $129,557-584$.

Urbanek, A. 1970. Neocucullograptinae n. subfam. (Graptolithina) - their evolutionary and stratigraphic bearing. Acta palaeontol. Polon. 15, 164-388.

W a 11 is e r, O. H. 1964. Conodonten des Silurs. Abh. hess. Landesanst. Bodenforsch., $41,106 \mathrm{~s}$.

Walliser, O. H. 1971. Conodont Biostratigraphy of the Silurian of Europe. Geol. Soc. Amer., Memoir, 127, 195-206.

Wa $1 \mathrm{msley}$, V. G., Aldridge, R. J., A ustin, R. L. 1974. Brachiopod and conodont faunas from the Silurian and Lower Devonian of Bohemia. Geol. et Palaeontol., 8, 39-47.

А ал оэ А., Кальо Д., Кл а ам анн Э., Н естор Х., Эйн а с то Р. 1976. Стратиграфическая схема силура Эстонии. Изв. АН ЭССР, Хим. Геол., 25, 38-45.

В и й р а В. Я. 1977. Состав и распространение конодонтов в силуре Прибалтики (скв. Oхесааре, Кункояй, Укмярге и др.). В кн.: Фащии и фауна силура Прибалтики. Таллин, с. $179-192$.

Гайли те Л. К., Р ыбников а М. В., У льст Р. Ж. 1967. Стратиграфия, фауна и условия образования силурийских пород Средней Прибалтики. Рига, 304 с.

Г а йли т е Л. К., У льст Р. Ж. 1974. Зональные подразделения верхнего силура в Латвин. В кн.: Региональная геология Прибалтики. Рига, с. 38-44.

К альо Д., С ар в Л. 1976. Расчленение верхнего силура в разрезе скв. Дубовское (Калининградская область). Изв. АН ЭССР, Хим. Геол., 25, 325-333.

Корень Т. Н., Кальо Д. Л. 1976. Граптолитовая зональная шкала снлура. В кн.: Граптолиты и стратиграфия. Таллин, с. $64-84$.

С а р в Л. И. 1968. Остракоды Craspedobolbinidae, Beyrichiidae и Primitiopsidae силура Әстонии. Таллин, $103 \mathrm{c}$.

С а р в Л. 1971. Силурийские остракоды в разрезе скважины Охесааре. Изв. АН ЭССР, Хим. Геол., 20, 349-355.

С ар в Л. И. 1977. К расчленению разрезов верхнего силура Средней и Южной Прибалтики по остракодам. В кн.: Фации и фауна силура Прибалтикн. Таллин, c. $159-178$.

Institute of Geology

Academy of Sciences of the Estonian SSR
Received Jul., 8, 1977

\section{KALJO}

\section{DAUNTON VOI PRIDOLI? (Balti siluri seisukohast)}

Ida-Balti, Gotlandi ja Poola ülemsiluri läbilōigete korrelatsioon (tab.) Inglise ja Tšehhoslovakkia stratotüüpidega graptoliitide, konodontide ja ostrakoodide pōhjal näitab, et dauntoni ja pridoli alumine piir on erineval tasemel. Esimesel juhul langeb see kokku kuressaare lademe ja selle analoogide ülemise, teisel juhul alumise piiriga. See erinevus ei luba kasutada ülemsiluri ladejärkude seganomenklatuuri (ladlou ja pridoli), vaid ainult nimetusi «ladlou» ja «daunton».

\section{Д. КАЛЬО}

\section{ДАУнТОН или ПРЖидоли? (С точки зрения Балтийского силура)}

Корреляция разрезов верхнего силура Прибалтики, о-ва Готланд и Польши со стратотипами Англии и Чехословакии (см. таблицу), проведенная на основе граптолитов, конодонтов и остракод, показывает, что нижняя граница даунтона и она же пржидоли находятся на разных уровнях. Первая совпадает с кровлей курессаареского горизонта и его аналогов, вторая - c его подошвой. По этой причине следует пользоваться не смешанной номенклатурой ярусов (лудлов и пржидоли) верхнего силура, а названиями лудлов и даунтон. 